\title{
A BENEFIT-COST ANALYSIS OF TEN STREET TREE SPECIES IN MODESTO, CALIFORNIA, U.S.
}

\author{
by E. Gregory McPherson
}

\begin{abstract}
Tree work records for ten species were analyzed to estimate average annual management costs by dbh class for six activity areas. Average annual benefits were calculated by dbh class for each species with computer modeling. Average annual net benefits per tree were greatest for London plane (Platanus acerifolia) (\$178.57), hackberry (Celtis sinensis) (\$148.42), and Modesto ash (Fraxinus velutina 'Modesto') (\$126.16) and least for pear (Pyrus calleryana cvs.) (\$33.65), pistache (Pistacia chinensis) (\$64.98), and camphor (Cinnamomum camphora) (\$71.36). Benefit-cost ratios (BCRs) were greatest for plane (24.3:1), ginkgo (7.4:1), and camphor $(7.3: 1)$. Species with the lowest BCRs were sweetgum (Liquidambar styraciflua) (2.4:1), pear (2.6:1), and pistache (3.3:1). Aging of sweetgum and Modesto ash will result in reduced net benefits because BCRs decreased once trees reached the $46 \mathrm{~cm}$ dbh class. Uses of benefit-cost data to increase future net benefits are discussed.
\end{abstract}

Key Words. Urban forest valuation; economic analysis; tree selection; benefit-cost analysis.

The diversity, stability, and functionality of urban forests are directly influenced by the type of trees selected to plant. At the scale of city blocks and neighborhoods, tree selection addresses such issues as optimizing stocking levels, increasing species and age diversity, and blending with the existing historic and cultural context (Arnold 1980; Flemer 1981; Richards 1992). At the scale of an individual tree planting site, the paramount concern is matching tree growth requirements to site characteristics, thereby promoting tree survival and health while minimizing conflicts with power lines, hardscape, visibility, and other vegetation (Gilman 1997; Watson and Himelick 1997; Harris et al. 1999). Good tree selection choices over the long term should result in relatively healthy, productive, and sustainable urban forests, with benefits far exceeding management costs (Clark et al. 1997). Although studies have described aspects of tree management that influence expenditures (Miller and Sylvester 1981; O'Brien and Joehlin 1992; O'Brien et al. 1992; Zillmer et al. 2000; McCabe 2002) and benefits (Peper et al. 2001), none have provided a full accounting of benefits and costs over the life span of a species as a basis for informed tree selection.

An analysis of the municipal urban forest in Modesto, California, U.S., found that for every $\$ 1$ spent on management annually, benefits valued at $\$ 1.89$ were returned to residents (McPherson et al. 1999a). Although this information helped the program retain funding despite cutbacks to other departments, it did not provide managers with a full accounting of benefits and costs by species. Annual benefits associated with individual tree species were quantified, but costs were not reported by species. The purpose of this study was to extend the Modesto benefit-cost analysis to the level of individual street tree species to answer the following questions:

- Which species have the highest and lowest benefit-cost ratios and why?

- How will aging of the tree population influence the distribution of benefits and costs?

- How can this type of information be applied by managers to increase future net benefits?

\section{METHODS \\ Annual Costs}

In 1998, Modesto's street tree inventory database contained 75,649 trees and 184 species. For this study, tree work records for 3 years (1996-1998) were obtained for ten of the most abundant species. These ten species accounted for $61.3 \%$ of the street tree population. Each of the 33,858 work records described the type of activity performed, time spent to the closest 0.1 hour, date the work was performed, tree species, planting date, and location. After an initial analysis of frequency distributions, each of the 240 activity codes was put into one of six activity areas: pruning, removal, plant/water/restake, root-related work, liability/ storm clean-up, and integrated pest management (IPM)/ other.

Most cities track costs based on tree diameter at breast height (dbh, diameter measured at $1.4 \mathrm{~m}$ above ground) classes. For Modesto, planting dates were converted to tree age, and the corresponding dbh for a tree of that age was determined using the growth curve for that species (Peper et al. 2001). Growth curves were regression equations that predicted dbh from age based on a sample of approximately 30 trees of each species. Each tree was assigned to the appropriate dbh size class ( $10 \mathrm{~cm}$ increments).

To estimate work costs, the 1991 figure of $\$ 96 /$ hour was increased to the 1998 value of $\$ 115$ /hour using a consumer price index (W. Dufresne, Muncipal Arborist, City of Modesto, pers. comm. 2002). This amount includes all direct and 
indirect costs and is used by the Community Forestry Division for budgeting.

The following information was calculated by dbh class for each species and work activity area to depict the amount and cost of work performed:

- average annual percentage of trees visited = (total visits/ total trees)/3

- average annual cost per tree visited = (total cost/ number of trees visited)/3

- average annual cost per tree $=($ total cost/total trees $) / 3$

\section{Annual Benefits}

Methods used to estimate annual benefits for 1998 were summarized in McPherson et al. (1999a) and described in detail in a technical report (McPherson et al. 1999b). Energy savings, atmospheric carbon dioxide reductions, air-quality benefits, stormwater runoff reductions, and aesthetic and other benefits were calculated with models that directly connected benefits with tree size variables such as dbh and leaf surface area. Many functional benefits of trees are related to leaf-atmosphere processes (e.g., interception, transpiration); therefore, benefits increase as tree canopy cover and leaf area increase. Prices were assigned to each benefit through direct estimation and implied valuation. For example, marginal electricity $(0.079 / \mathrm{kWh})$ and natural gas ( $\$ 0.81 /$ therm) prices in 1998 were used to estimate energy savings. Air-quality benefits were estimated using transaction costs that reflected the average market value of pollution emission credits from 1994 through 1997 for the San Joaquin Valley Unified Air Pollution Control Management District. Benefits were originally calculated by tree age classes and converted to corresponding dbh classes (Maco 2000).

Average annual benefits were calculated on a per-tree basis by type of benefit for each species by dbh class. Total benefits were estimated by multiplying annual per-tree benefits by total numbers of trees in each dbh class.

\section{Benefit and Cost Calculations}

Average annual net benefits (benefits - costs) and benefit-cost ratios (benefits/costs, BCR) were calculated for each species and by dbh class on a per-tree basis. A species with the highest net benefit may not have the highest BCR. Net benefits are sensitive to the overall magnitude of benefits and favor large-stature trees. $\mathrm{BCR}$ reflect the magnitude of benefits relative to costs and are a better indicator of value than net benefits when costs are constrained.

\section{RESULTS \\ Tree Locations and Size Class Distributions}

Six species had $75 \%$ or more of their populations located in front-yard easements within $3.5 \mathrm{~m}$ of a sidewalk or street (Table 1). Exceptions were ginkgo (Ginkgo biloba) and Southern magnolia (Magnolia grandiflora), with 31\% and 60\% in cutouts, respectively, and Chinese pistache (Pistacia chinensis) and London plane (Platanus acerifolia), with 17\% and $56 \%$, respectively, in parkways between sidewalk and curb. Generally, growing conditions were most restrictive in cutouts and best in front yards. Parkway strips were typically 1.2 to $1.8 \mathrm{~m}$ wide and limited to streets constructed before 1960. Hence, trees there tended to be large and old or younger replacements.

The four most abundant species were Chinese pistache $(10,199)$, Modesto ash (Fraxinus velutina 'Modesto') $(8,024)$, cultivars of Callery pear (Pyrus calleryana cvs.) (7,265, 56\% Bradford, 28\% Aristocrat, 9\% Capital), and Japanese zelkova (Zelkova serrata) $(5,190)$. Pistache, pear, and zelkova exhibited bimodal size distributions, with peak numbers in the 10 to $20 \mathrm{~cm}$ and 30 to $46 \mathrm{~cm}$ dbh classes (Figure 1). Nearly all Modesto ash were greater than $46 \mathrm{~cm}$ dbh. Ginkgo were relatively evenly distributed among size classes. Chinese hackberry (Celtis sinensis) and American sweetgum (Liquidambar styraciflua) were heavily planted 20 to 40 years ago, as evidenced by large numbers in the 30 to $46 \mathrm{~cm}$ size class. However, recent disease and maintenance problems have resulted in reduced planting rates. Sixty percent of all plane were greater than $60 \mathrm{~cm} \mathrm{dbh}$, and a resurgence in popularity is reflected by tree numbers in the smaller size classes. Camphor tree (Cinnamomum camphora) and Southern magnolia were consistently planted during the past 40 years in relatively small numbers.

\section{Average Annual Benefits per Tree}

Total average annual benefits per tree reflected tree distribution by size classes. Plane, Modesto ash, and hackberry had many large trees, and total annual benefits ranged from $\$ 175$
Table 1. Tree numbers, locations, and average annual number of visits and hours spent performing tree work.

\begin{tabular}{lllllll}
\hline Species & No. trees & Front yard \% & Parkway \% & Cutout & \% Visits/yr & Hours/yr \\
\hline Hackberry & 4,454 & 87.0 & 12.3 & 0.7 & 1,233 & 1,266 \\
Camphor & 1,276 & 74.5 & 20.8 & 4.6 & 207 & 127 \\
Modesto ash & 8,024 & 95.6 & 3.6 & 0.9 & 1,965 & 3,405 \\
Ginkgo & 3,462 & 59.7 & 9.3 & 31.1 & 515 & 400 \\
Sweetgum & 2,892 & 90.9 & 2.6 & 6.5 & 928 & 1,366 \\
Southern magnolia & 928 & 33.8 & 6.0 & 60.2 & 218 & 165 \\
Pistache & 10,199 & 72.5 & 16.9 & 10.6 & 2,946 & 2,464 \\
Plane & 2,038 & 25.6 & 55.5 & 18.8 & 272 & 136 \\
Pear* & 7,265 & 81.4 & 5.6 & 13.0 & 1,850 & 1,323 \\
Zelkova & 5,190 & 91.5 & 7.7 & 0.8 & 1,152 & 954 \\
Totals & $\mathbf{4 5 , 7 2 8}$ & & & & $\mathbf{1 1 , 2 8 6}$ & $\mathbf{1 1 , 6 0 6}$ \\
\hline
\end{tabular}

*56\% Bradford, 28\% Aristocrat, 9\% Capital, 7\% other. 
to $\$ 186$ per tree (Table 2). Benefits for species with more younger, medium-sized trees ranged from $\$ 83$ (camphor) to $\$ 124$ (zelkova). Average annual total benefits were lowest for the smaller pear trees $(\$ 55)$.

Average annual energy savings represented the greatest benefit category for every species and ranged from $\$ 34$ for pear to $\$ 137$ for plane. Energy savings accounted for as much as $85 \%$ of total benefits for Southern magnolia and as little as $53 \%$ for ginkgo. Many magnolia were located in cutouts where they shaded commercial buildings with higher air-conditioning loads than residential structures of similar size. Small crown volumes and sparse shade from ginkgos explain their relatively poor energy conservation performance.

Air-quality benefits showed a similarly surprising range among species, from $\$ 2$ (magnolia) to $\$ 53$ (Modesto ash) per tree. Because calculations of pollutant uptake were sensitive to crown diameter, species with many large-stature trees had the highest average values (i.e., plane and hackberry), while species with smaller amounts of average canopy cover had lowest values (i.e., ginkgo, pear).

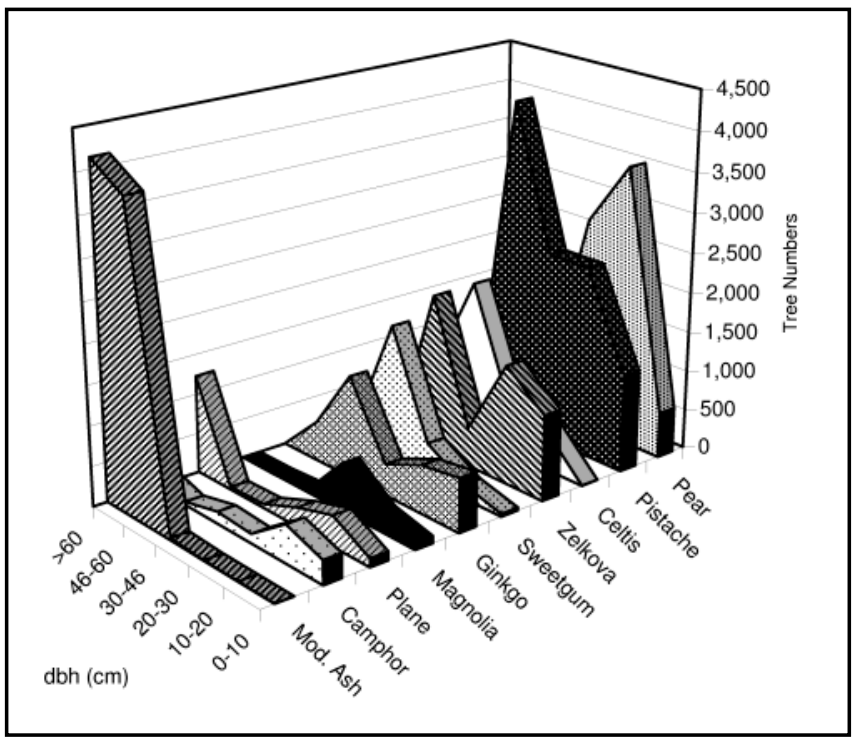

Figure 1. Distribution of tree numbers among species by dbh class.

Table 2. Average annual benefits in dollars (U.S.) per tree.

\begin{tabular}{lllllll}
\hline & Energy & Air quality & $\mathrm{CO}_{2}$ & Stormwater & Aesthetics & Total \\
\hline Hackberry & 118.30 & 19.82 & 7.05 & 8.23 & 27.69 & 181.09 \\
Camphor & 54.29 & 7.62 & 2.85 & 6.71 & 11.29 & 82.75 \\
Modesto ash & 97.83 & 52.61 & 7.67 & 11.19 & 5.67 & 174.96 \\
Ginkgo & 51.51 & 2.79 & 5.43 & 3.27 & 35.18 & 98.18 \\
Sweetgum & 79.88 & 10.16 & 6.29 & 5.24 & 31.38 & 132.95 \\
Southern magnolia & 79.44 & 2.42 & 2.81 & 2.79 & 6.15 & 93.61 \\
Pistache & 65.31 & 10.27 & 2.82 & 3.34 & 11.03 & 92.76 \\
Plane & 136.76 & 25.76 & 4.80 & 7.59 & 11.33 & 186.24 \\
Pear & 34.00 & 2.98 & 1.95 & 1.47 & 14.19 & 54.59 \\
Zelkova & 89.25 & 8.26 & 4.69 & 3.37 & 18.47 & 124.05 \\
\hline
\end{tabular}

Average annual aesthetic and other benefits per tree varied less drastically among species. Values were greatest ( $\$ 28$ to $\$ 35)$ for species with a majority of trees growing rapidly (i.e., ginkgo, sweetgum, hackberry), which corresponded with the 30 to $46 \mathrm{~cm}$ dbh class. Values were lowest for Modesto ash (\$5) and magnolia (\$6), with the age of most trees well beyond the early functional period. These differences among species reflect the modeling assumption that average annual aesthetic benefits depended on annual change in tree leaf surface area (McPherson et al. 1999b).

Stormwater runoff reduction benefits accounted for 3\% to $8 \%$ of total benefits. Modesto ash trees had the highest average annual benefit (\$11) due to their large amount of leaf surface area. Pear, magnolia, ginkgo, pistache, and zelkova had the lowest values ( $\$ 1$ to $\$ 3$ ).

The magnitude of atmospheric carbon dioxide $\left(\mathrm{CO}_{2}\right)$ reductions were similar to stormwater runoff reduction benefits. Again, Modesto ash (\$11) and hackberry (\$8) provided the highest average annual benefits per tree, while benefits were least for the smaller pear (\$2), magnolia, (\$3), pistache (\$3), and camphor (\$3). Results were sensitive to tree growth rates, which influence $\mathrm{CO}_{2}$ sequestration rates, and tree sizes, which influence energy savings and associated avoided $\mathrm{CO}_{2}$ power plant emissions.

The magnitude of benefits produced by trees in different dbh size classes varied by species due to differences in their growth rates and dimensions (Figure 2). For example, annual per-tree benefits for the pear increased gradually until trees reached their mature size, the 30 to $46 \mathrm{~cm}$ dbh class. The $\$ 66$ per-tree average annual benefit for slowergrowing camphor in the 20 to $30 \mathrm{~cm}$ dbh class was substantially less than $\$ 84$ and $\$ 107$ for same-sized pear and Chinese hackberry, respectively. Once camphor reached 60 $\mathrm{cm}$ dbh, estimated annual benefits (\$277) were comparable to the faster-growing hackberry.

\section{Average Annual Costs per Tree}

Total average annual costs per tree ranged from $\$ 7.66$ for plane to $\$ 54.31$ for sweetgum (Table 3). Other high-cost species were Modesto ash (\$48.80) and hackberry $(\$ 32.67)$. Low-cost species were camphor $(\$ 11.40)$ and ginkgo

(\$13.28). On average, California cities spend \$19 per tree annually (Thompson and Ahern 2000). As expected, species with large numbers of big trees $(>30 \mathrm{~cm})$ cost the most to manage. Plane tree was the exception. Although $60 \%$ of all plane were $>60$ $\mathrm{cm}$ dbh, per-tree management expenditures were remarkably low $(\$ 7.66)$.

Pruning was the single greatest cost category for every species, accounting for more than $73 \%$ of total per-tree 
costs for every species except ginkgo (49\%). Species with the highest percentages of total costs spent for pruning were Modesto ash (93\%), sweetgum (92\%), pistache (90\%), hackberry (90\%), and pear (87\%).

Two factors influenced pruning costs: frequency of visits to prune and the time and cost for each pruning. The former was expressed as the percentage of all trees visited annually for pruning (percentage visited, Table 4). The latter amount, expressed as average dollars per tree visited, depended on the type and amount of pruning. Pruning frequency ranged from $8.5 \%$ (ginkgo) to $25.1 \%$ (sweetgum), corresponding to 12 year and 4-year pruning cycles, respectively. Ginkgos required training and periodic raising for clearance as they matured, but relatively little crown thinning or cleaning after establishment. Other species that required infrequent pruning were plane (9.8\%), camphor (11.4\%), and zelkova

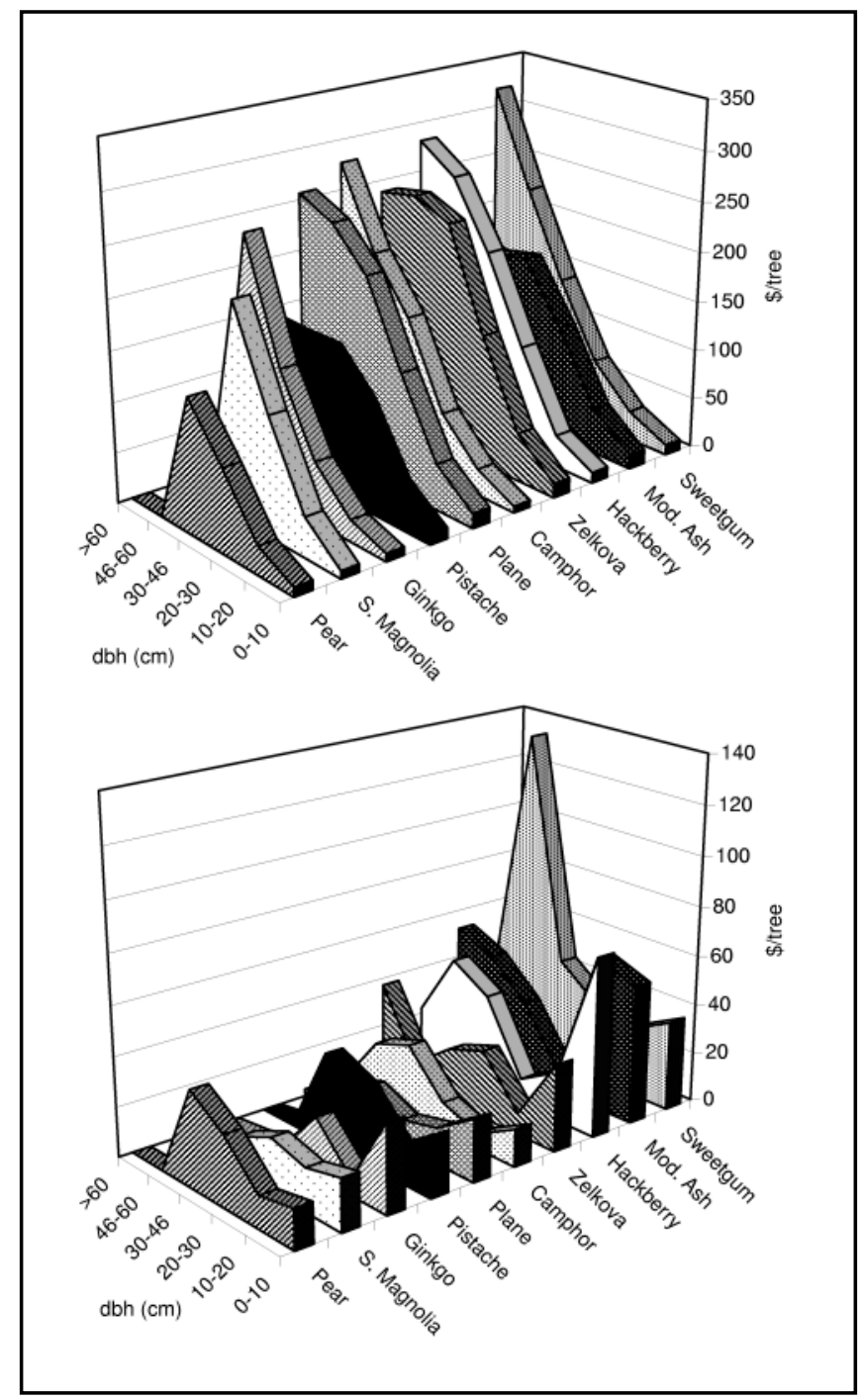

Figure 2. Distribution of average annual per-tree benefits (top) and costs (bottom) among species by dbh class.
(15.3\%). Sweetgums required frequent crown reduction due to heavy fruit that cause limb breakage. Other species that required frequent pruning were pistache (24.7\%), hackberry (23.8\%), and pear (21.2\%).

The average cost per tree pruned ranged from $\$ 63$ (plane) to $\$ 226$ (Modesto ash). Although most trees pruned were large for both of these species, the type of pruning was different. Crown cleaning to remove deadwood and raising for clearance were the primary activities performed on plane due to their excellent overall structure. Work on the Modesto ash involved more costly mistletoe removal and crown reduction due to frequent failure of heavy lateral limbs. Ninety percent of Modesto ash's total average annual pruning expenditure was for general pruning (i.e., crown cleaning, thinning, and reduction) of trees with dbh exceeding $46 \mathrm{~cm}$ (Table 4). Sweetgum also had a high average cost (\$198). For most species, the average annual cost per visit ranged from $\$ 60$ to $\$ 100$ per tree.

The average annual pruning cost per tree was least for plane, ginkgo, and camphor (\$6 to \$8), moderately high for pistache and hackberry ( $\$ 25$ and $\$ 29)$, and highest for Modesto ash and sweetgum ( $\$ 45$ and $\$ 50)$.

The allocation of pruning resources by activity varied among species (Table 4). For example, relatively more was spent on young tree pruning (i.e., training) of slower-to-establish species such as camphor (2.5\%) and ginkgo (1.3\%) than the other species. Crown raising for clearance required more than $20 \%$ of total annual pruning expenditures for Southern magnolia and ginkgo, many of which were in cutouts. Tree inspection and other miscellaneous pruning-related activities were proportionately more costly for these two species, due in part to higher numbers in more prominent locations. As expected, the bulk of pruning costs were for general pruning, and expenditures reflected the distribution of tree numbers among dbh size classes.

Removal costs followed pruning as the second most important cost category. When expenditures were averaged for all trees, they ranged from $\$ 0.59$ (plane) to $\$ 3.42$ (ginkgo) per tree. Relatively high removal costs for ginkgo ( $26 \%$ of total), camphor (15\%), and zelkova (12\%) were primarily due to high rates of establishment-related mortality. Surprisingly, removal costs were lowest (2\%) for Modesto ash and sweetgum as a percentage of total costs. Although the average cost per Modesto ash tree removed was highest of all species (\$305), removal frequency was lowest (0.3\%). Substantial resources were allocated to maintain the safety and health of these two species, instead of for removal and replacement.

Planting and establishment costs were less than $\$ 1$ per tree for all species except ginkgo (\$2.18) and camphor (\$1.05). These expenditures accounted for 16\% and 9\% of their total costs, respectively. Expenditures related to damage from tree roots to sidewalks and curbs (i.e., root cutting, cement cutting, root barriers, site inspection) were highest for sweetgum (\$2.14), Modesto ash (\$1.43), and zelkova (\$1.09) 
Table 3. Average annual costs in dollars per tree.

\begin{tabular}{llllllll}
\hline & Prune & Remove & Plant & Root-related & Storm/liability & IPM/other & Total \\
\hline Hackberry & 29.30 & 1.43 & 0.01 & 0.88 & 0.76 & 0.29 & 32.67 \\
Camphor & 8.34 & 1.78 & 1.05 & 0.14 & - & 0.09 & 11.40 \\
Modesto ash & 45.22 & 0.83 & 0.01 & 1.43 & 0.37 & 0.93 & 48.80 \\
Ginkgo & 6.56 & 3.42 & 2.18 & 0.75 & 0.24 & 0.14 & 13.28 \\
Sweetgum & 49.70 & 0.90 & 0.03 & 2.14 & 0.62 & 0.92 & 54.31 \\
Southern magnolia & 17.38 & 1.13 & 0.03 & 0.95 & 0.70 & 0.19 & 20.38 \\
Pistache & 25.06 & 1.54 & 0.39 & 0.44 & 0.19 & 0.16 & 27.78 \\
Plane & 6.14 & 0.59 & 0.51 & 0.27 & 0.02 & 0.13 & 7.66 \\
Pear & 18.55 & 1.27 & 0.20 & 0.53 & 0.26 & 0.12 & 20.94 \\
Zelkova & 16.01 & 2.60 & 0.78 & 1.09 & 0.42 & 0.24 & 21.14 \\
\hline
\end{tabular}

Table 4. Average annual pruning costs and their distribution by type (GP $<20$ is general pruning of trees $<20 \mathrm{~cm}$ dbh, where GP includes crown cleaning, thinning, and reduction).

\begin{tabular}{llllllllll}
\hline & & & \multicolumn{5}{c}{ \% of total pruning expenditure } \\
\cline { 6 - 10 } & \% visited & \$/visit & \$/tree & Train & Raise & Other & GP <20 & GP 20-46 & GP $>46$ \\
\hline Hackberry & 23.8 & 123 & 29 & 0.1 & 7.1 & 7.7 & 6.6 & 50.0 & 28.5 \\
Camphor & 11.4 & 73 & 8 & 2.5 & 16.6 & 10.1 & 21.3 & 40.7 & 8.9 \\
Modesto ash & 20.0 & 226 & 45 & 0.0 & 0.6 & 9.2 & 0.1 & 0.2 & 89.9 \\
Ginkgo & 8.5 & 77 & 7 & 1.3 & 21.6 & 27.7 & 21.8 & 27.4 & 0.2 \\
Sweetgum & 25.1 & 198 & 50 & 0.0 & 2.1 & 15.8 & 2.2 & 45.8 & 34.1 \\
Southern magnolia & 20.0 & 87 & 17 & 0.1 & 25.6 & 24.5 & 12.7 & 37.1 & 0.0 \\
Pistache & 24.7 & 102 & 25 & 0.4 & 8.0 & 18.8 & 13.3 & 59.4 & 0.0 \\
Plane & 9.8 & 63 & 6 & 1.0 & 11.2 & 11.3 & 29.8 & 21.1 & 25.6 \\
Pear & 21.2 & 88 & 19 & 0.7 & 6.9 & 14.8 & 27.4 & 50.2 & 0.0 \\
Zelkova & 15.3 & 104 & 16 & 0.4 & 10.3 & 9.6 & 29.2 & 48.8 & 1.6
\end{tabular}

but did not account for more than $6 \%$ of total costs for any species. Despite having large numbers of trees with dbhs exceeding $60 \mathrm{~cm}$ and $75 \%$ of all trees being in planting strips or cutouts, root repair costs for plane $(\$ 0.44)$ were the least of all species. Storm (e.g., inspection, removal, prune broken limb, inspection) and liability (private property repairs) expenditures were relatively small overall, less than $4 \%$ of total costs. Species with the highest costs due to limb breakage or other types of failures were hackberry $(\$ 0.76)$, Southern magnolia (\$0.70), and sweetgum (\$0.62). IPM and other costs (e.g., training, meetings, water jetting, cabling, public information) accounted for less than $2 \%$ of total expenditures. IPM and other costs were greatest for Modesto ash (\$0.93) and sweetgum (\$0.92) and least for camphor, plane, pear, and ginkgo ( $\$ 0.09$ to $\$ 0.14$ ).

\section{Average Annual Net Benefits per Tree and Benefit-Cost Ratios}

Average annual net benefits were greatest for plane (\$178.57), hackberry (\$148.42), and Modesto ash (\$126.16) and least for pear (\$33.65), pistache (\$64.98), camphor (\$71.36), and Southern magnolia (\$73.23) (Table 5). The benefit-cost ratio (BCR) for the plane was 24.3:1, or more than three times greater than for the next closest species: ginkgo (7.4:1) and camphor (7.3:1). Species with the lowest BCRs were sweetgum (2.4:1), pear (2.6:1), pistache (3.3:1), and Modesto ash (3.6:1).

\section{DIscussion}

Of the ten species evaluated, London plane was the outstanding performer. There were 2,038 planes in Modesto, of which $60 \%$ were $60 \mathrm{~cm}$ or greater dbh. The species combined maximum benefits with minimum costs. The Modesto municipal arborist confirmed that plane rarely require pruning, have high establishment rates, rarely heave sidewalks, and are not prone to storm damage. Anthracnose and powdery mildew occasionally disfigure trees but seldom result in mortality. This species accounted for only $2.7 \%$ of the street tree population, so increased planting is warranted.

Ginkgo and camphor were the next best performers. Although slow to establish and prone to early losses, these species are worth the wait. Once trained and established, they required very little care. Their benefits did not rival those produced by the larger plane and hackberry but were nonetheless substantial. Perhaps most important, BCRs increased dramatically for trees in the largest size classes. For example, assuming all 1,290 ginkgo increase in size from 30 to $46 \mathrm{~cm}$ $\mathrm{dbh}(\mathrm{BCR}=23.2: 1)$ to 46 to $60 \mathrm{~cm}$ dbh $(\mathrm{BCR}=129.4: 1)$, annual net benefits should increase from about $\$ 30,000$ to $\$ 167,000$. 
Table 5. Average annual per-tree benefits, costs, net benefits, and benefit-cost ratios.

\begin{tabular}{lllll}
\hline Species & Benefit & Cost & Net benefit & B/C \\
\hline Plane & 186.24 & 7.66 & 178.57 & 24.3 \\
Ginkgo & 98.18 & 13.28 & 84.90 & 7.4 \\
Camphor & 82.75 & 11.40 & 71.36 & 7.3 \\
Zelkova & 124.05 & 21.14 & 102.91 & 5.9 \\
Hackberry & 181.09 & 32.67 & 148.42 & 5.5 \\
Southern magnolia & 93.61 & 20.38 & 73.23 & 4.6 \\
Modesto ash & 174.96 & 48.80 & 126.16 & 3.6 \\
Pistache & 92.76 & 27.78 & 64.98 & 3.3 \\
Pear & 54.59 & 20.94 & 33.65 & 2.6 \\
Sweetgum & 32.95 & 54.31 & 78.64 & 2.4 \\
\hline
\end{tabular}

Zelkova, hackberry, and Modesto ash were large shade trees that grew relatively rapidly and produced sizable annual benefits. Management costs were relatively high for the Modesto ash and hackberry because many trees were at the end of their functional lifecycle. Today, Modesto ash and Chinese hackberry are rarely planted due largely to high costs required to maintain older trees and high loss rates for hackberry due to root rot disease. Zelkova continues to be planted in large numbers. A BCR of 25.1:1 for 46 to $60 \mathrm{~cm}$ dbh zelkova indicates that net benefits for this species will increase substantially as a large cohort of 1,985 trees moves up from the 30 to $46 \mathrm{~cm}$ size class ( $\mathrm{BCR}=10.4: 1$ ).

Southern magnolia has proved to be a reliable performer ( $B C R=4.6: 1)$, especially in commercial areas where smallerstature trees were required. Annual benefits averaged $\$ 93.61$ per tree, near the maximum for this species because $64 \%$ were in their mature 20 to $30 \mathrm{~cm}$ dbh class. Pistache and sweetgum were medium-stature species with large numbers of trees in the 30 to $46 \mathrm{dbh}$ class. Pistache had substantial numbers of individuals in smaller size classes, indicating continuous planting, whereas planting of sweetgum was discontinued after management problems with older trees became evident (Figure 3). The low BCR for sweetgum (2.4:1) can be expected to drop further as trees in the $30-46 \mathrm{~cm}$ dbh class move into the 46-60 cm size class with a BCR of 1.7:1.

Pear had a relatively low BCR (2.6.1) because annual benefits were the least of all ten species due to small tree sizes (\$54.59), but costs also were relatively low (\$20.94). The Bradford cultivar has proved to have high limb failure rates due to poor structure. Profuse fruiting by Aristocrats have made it an unpopular cultivar. Few pear currently are planted, but net benefits for the species should increase as trees age because BCRs steadily increase by dbh class to 3.4:1 (30 to $46 \mathrm{~cm}$ ) (Figure 3).

\section{Limitations}

This study did not involve sampling; therefore, sampling error and variability are not described statistically. However, there are other sources of uncertainty that merit discussion.

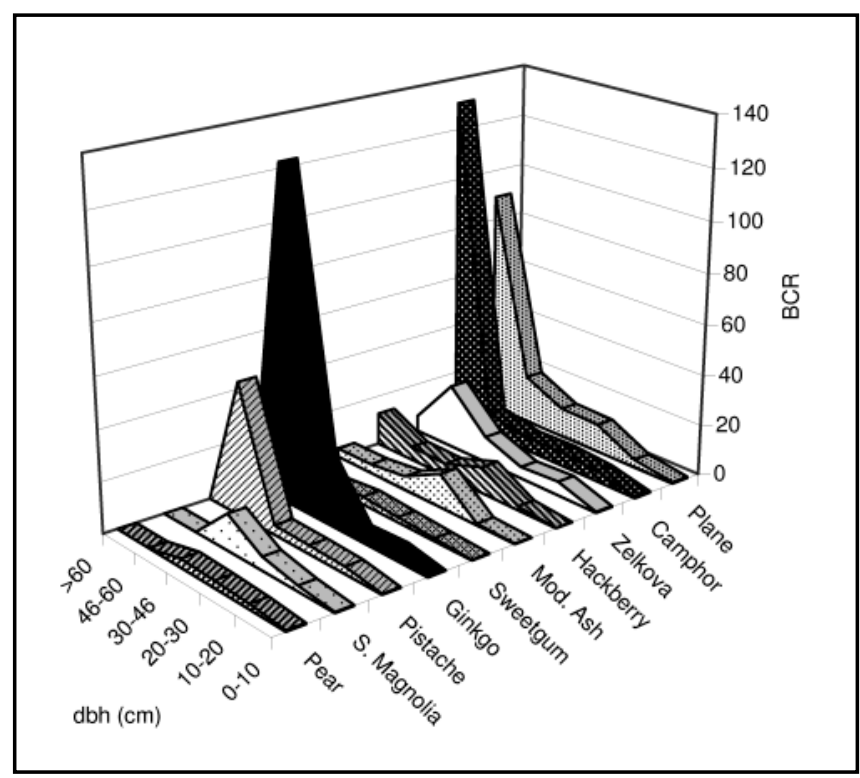

Figure 3. Distribution of benefit-cost ratios (BCR) among species by dbh class.

Uncertainty of cost estimates were greatest for species and size classes with the fewest tree numbers (i.e., Southern magnolia and camphor). Variability in tree growth and dimensions increased with age (Peper et al. 2001), so the level of uncertainty in estimated benefits increased with tree size. Also, many of the architectural and physiological features of each species that influence pollutant uptake (e.g., gas exchange rates, leaf sizes) and rainfall interception (e.g., leaf and stem surface detention, foliation periods) have not been fully included in benefit models. Further research is needed to better describe how species differences beyond crown size and leaf area influence benefits.

These results are specific to Modesto, California, and cannot be directly applied to other communities. However, this approach can be adopted to compare BCRs of important species where adequate work histories and benefit information are available.

\section{Uses of This Type of Information}

Controlling management costs has been central to tree selection because of constrained budgets and a dearth of information on species-related benefits. Increased planting of small-stature species in California is partially a response to reduced funding for tree care programs (Thompson and Ahern 2000). BCRs provide new information for tree selection. By incorporating the stream of benefits as well as costs, BCRs indicate relative return on investment by species. One way to increase urban forest sustainability is to increase the proportion of tree species with relatively high BCRs and reduce those with low BCRs, while not compromising overall age and species diversity. In Modesto, this objective can be accomplished by increased planting of 
plane, ginkgo, and camphor-species that each account for less than $5 \%$ of the street tree population. Continued phase-out of pear and sweetgum, as well as reduced planting of pistache, already $13 \%$ of the population, is recommended.

Information on cost components can help target management activities. For example, relatively high rates of establishment-related mortality for ginkgo and camphor indicate need for further study of causes and possible solutions, such as planting larger or smaller size stock, more frequent watering, and different staking and protection.

The relative magnitude of benefits varies among species. For instance, $30 \%$ of total benefits produced by Modesto ash were for air-quality improvement due to their large amount of leaf and stem surface areas. Selecting largestature trees similar to Modesto ash for planting along transportation corridors could maximize these benefits if space permitted.

BCRs by dbh class provide a basis for projecting future costs and benefits associated with aging tree populations. In Modesto, BCRs increased with size for most species. Exceptions were Modesto ash and sweetgum, where BCRs decreased once trees reached the $46 \mathrm{~cm}$ dbh class. By combining information on tree numbers and BCRs by size class, municipal arborists can estimate how net benefits will change as trees move into larger size classes. This information may influence budgeting for tree removal and replacement, pruning, planting, and sidewalk repair.

By documenting future benefits and costs associated with maturing street tree populations, municipal foresters have a quantitative basis for justifying investment in tree health and longevity. They can use these data to indicate how failure to invest in management will result in reduced net benefits as costs increase relative to benefits. Alternatively, the consequences of targeting management actions to increase BCRs can easily be described and readily understood by decision-makers and the public.

Setting appropriate tree canopy cover targets provides measurable goals for urban forest planning and management. However, this study suggests that the type of tree cover is just as important as the amount of tree cover. Accounting for the benefits and costs of different tree species over the long-term should be one aspect of judicious tree selection.

\section{LITERATURE CITED}

Arnold, H.F. 1980. Trees in Urban Design. Van Nostrand Reinhold, New York, NY.

Clark, J.R., N.P. Matheny, G. Cross, and V. Wake. 1997. A model of urban forest sustainability. J. Arboric. 23:17-30.

Flemer, W. 1981. Mixing species of shade trees for beauty and safety. J. Arboric. 7:5763.
Gilman, E.F. 1997. Trees for Urban and Suburban Landscapes. Delmar Publishers, New York, NY.

Harris, R.W., J.R. Clark, and N.P. Matheny. 1999. Arboriculture: Integrated Management of Landscape Trees, Shrubs, and Vines. Prentice Hall, Upper Saddle River, NJ.

Maco, S.E. 2000. A Practical Approach to Assessing Structure, Function, and Value of Street Tree Populations in Small Communities. Masters Thesis, Department of Environmental Horticulture. University of California, Davis, CA.

McCabe, J. 2002. A discrete event simulation of a municipal street tree maintenance operation. J. Arboric. 28:131136.

McPherson, E.G., J.R. Simpson, P.J. Peper, and Q. Xiao. 1999a. Benefit-cost analysis of Modesto's municipal urban forest. J. Arboric. 25:235-248.

—. 1999b. Benefit-Cost Analysis of Modesto's Municipal Forest. USDA Forest Service, Western Center for Urban Forest Research and Education, Davis, CA.

Miller, R.W., and W.A. Sylvester. 1981. An economic evaluation of the pruning cycle. J. Arboric. 7:109-112.

O’Brien, P., and K. Joehlin. 1992. Use of municipal tree maintenance standards. J. Arboric. 18:273-277.

O'Brien, P., K. Joehlin, and D. O’Brien. 1992. Performance standards for municipal tree maintenance. J. Arboric. 18:307-315.

Peper, P.J., E.G. McPherson, and S.M. Mori. 2001. Equations for predicting diameter, height, crown width and leaf area of San Joaquin Valley street trees. J. Arboric. 27:306-317.

Richards, N. 1992. Optimum stocking of urban trees. J. Arboric. 18:64-68.

Thompson, R.P., and J.J. Ahern. 2000. The State of Urban and Community Forestry in California. Urban Forest Ecosystem Institute, San Luis Obispo, CA.

Watson, G.W., and E.B. Himelick. 1997. Principles and Practice of Planting Trees and Shrubs. International Society of Arboriculture, Champaign, IL.

Zillmer, R.E., J.L. Boeder, and K.G. Genich. 2000. A productivity timing system for tree climbing training. J. Arboric. 26:97-105.
Center for Urban Forest Research
USDA Forest Service, Pacific Southwest Research Station
C/O Dept. of Environmental Horticulture
University of California
Davis, CA 95616, U.S.
egmcpherson@ucdavis.edu 
Résumé. Des données de travaux sur les arbres de dix espèces différentes ont été analysées pour estimer les coûts annuels d'entretien par classe de DHP de six activités différentes. Les bénéfices annuels moyens ont été calculés par classes de DHP pour chaque espèce au moyen d'un modèle informatique. Les bénéfices annuels moyens par arbre étaient les plus élevés pour le Platanus acerifolia (178,57 \$), le Celtis sinensis (148,42 \$), et le Fraxinus velutina 'Modesto' (126,16\$), et les plus faibles pour le Pyrus calleryana cvs. (33,65 \$), le Pistacia chinensis $(64,98$ \$) et le Cinnamomum camphora $(71,36$ \$). Les ratios coût-bénéfice étaient les plus élevés pour le Platanus (24,3:1), le Ginkgo $(7,4: 1)$, et le Cinnamomum $(7,3: 1)$. Les espèces avec les ratios coût-bénéfice les plus bas étaient le Liquidambar $(2,4: 1)$, le Pyrus $(2,6: 1)$ et le Pistacia $(3,3: 1)$. Le vieillissement des copalmes d'Amérique et des frênes Modesto vont donner une réduction des bénéfices nets parce que les ratios coûtbénéfice diminuent une fois que les arbres atteignent la classe de DHP de $46 \mathrm{~cm}$. L'emploi des données de coûtbénéfice pour accroître les bénéfices futurs nets est discuté.

Zusammenfassung. Um die durchschnittlichen jährlichen Mehrkosten pro Durchmesserklasse zu analysieren, wurden die Arbeitsberichte für 10 Arten in 6 bewirtschafteten Bereichen ausgewertet. Die durchschnittlichen jährlichen Netto-Nutzenerträge/Baum waren am größten bei Platanus acerifolia $=\$ 178,57$, Celtis sinensis $=$ $\$ 148,42$, Fraxinus velutina Modesto $=\$ 126,16$ und am wenigsten bei Pyrus calleryana $=\$ 33,65$, Pistacia chinensis $=$ $\$ 64,98$ und Cinnamomum camphora $=\$ 71,36$. Die Nutzen-
Kosten-Verhältnisse (BCRs) waren am größten bei Platanus, 24,3:1, Ginkgo 7,4:1 und Cinnamomum 7,3:1. Arten mit niedrigem BCR waren Liquidamber 2,4:1, Calleryana 2,6:1, und Pistacia 3,3:1. Das Altern von Liquidamber und ModestoEsche führte zu reduzierten Nettovorteilen, weil die BCR ab einem Durchmesser von $46 \mathrm{~cm}$ absinken. Die Verwendung der Nutzen-Kosten-Daten in Bezug auf zukünftigen Nutzen wurde hier diskutiert.

Resumen. Se analizaron los registros en trabajos con los árboles en diez especies con el fin de estimar los costos de manejo por clases de dap (diámetro a la altura del pecho) para seis áreas de trabajo. Los promedios anuales de beneficios fueron calculados por clases de dap para cada especie mediante modelamiento en computadora. Los beneficios netos por árbol fueron mayores para London plane (Platanus acerifolia) (\$178.57), hackberry (Celtis sinensis) (\$148.42), y Modesto ash (Fraxinus velutina 'Modesto') (\$126.16) y menores para peral (Pyrus calleryana cvs.) (\$33.65), pistache (Pistacia chinensis) (\$64.98), y camphor (Cinnamomum camphora) (\$71.36). Las relaciones costo / beneficio (C/B) fueron mayores para plane (24.3:1), ginkgo (7.4:1), y camphor (7.3:1). Las especies con los más bajos C/ B fueron sweetgum (2.4:1), pear (2.6:1), y pistache (3.3:1). El envejecimiento de sweetgum y Modesto ash resultó en beneficios netos reducidos debido a que la relación C/B disminuyó una vez que los árboles alcanzaron los $46 \mathrm{~cm}$ de clase de dap. Se discute el uso de los datos costo-beneficio para incrementar los futuros beneficios netos. 